\title{
Література
}

1. Андреев В. И. Диалектика воспитания и самовоспитания творческой личности / В. И. Андреев. - Казань : Изд-во КГУ, 1988. - 240 с. 2. Артемьева О. А. Система учебно-ролевых игр профессиональной направленности : [монография] / О. А. Артемьева, М. Н. Макеева. - Тамбов : Изд-во Тамб. гос. техн. ун-та, 2007. - 208 с. 3. Википедия с описанием Google Earth. [Електронный ресурс] / Википедия. Режим доступа: http://ru.wikipedia.org/wiki/GoogleEarth. 4. Володарская Е. Б. Творчество как неотъемлемое требование к профессиональной компетентности преподавателя иностранных языков / Е. Б. Володарская, М. М. Степанова // Инновационные компетенции и креативность в исследовании и преподавании языков и культур : [сборник статей по материалам II Всероссийской (с международным участием) научнопрактической конференции, 20 ноября 2009 г., г. Москва]. - М. : РГСУ, 2009. - С. 124-127. 5. Лернер И. Я. Дидактические основы методов обучения / И. Я. Лернер. -М. : Педагогика, - 1981. 116с. 6. Эльконин Д. Б. Психология игры / Д. Б. Эльконин. - 2-е изд. - М. : Гуманитарный изд. центр «Владос», 1999. - 360 с.

УДК 372.018

C. M. Ibax,

кандидат пед. наук, доиент, Дрогобицький державний педагогічний університет імені Івана Франка

\section{ОСОБЛИВОСТІ ПЕДАГОГІЗАЦІЇ БАТЬКІВ ДІТЕЙ ДОШКІЛЬНОГО ВІКУ}

Івах С. М. Особливості педагогізації батьків дітей дошкільного віку.

У статті акцентовано на важливості тісного взаємозв'язку сім'ї та дошкільного навчального закладу задля створення для кожної дитини єдиного, дитиноцентричного виховного середовища; виокремлено основні засади їх взаємодії; обгрунтовано ефективні форми та методи їхньої співпраці.

Ключові слова: дошкільний навчальний заклад, сім'я, педагогізація батьків, взаємодія, співробітництво, партнерство.

Ивах С. М. Особенности педагогизации родителей детей дошкольного возраста.

В статье акцентируется на важности тесной взаимосвязи семьи и дошкольного учебного учреждения для создания каждому ребенку единой, детоцентричной воспитательной среды; выделяются основные засады их сотрудничества; обосновываются эффективные формы и методы их сотрудничества.

Ключевые слова: дошкольное учебное учреждение, семья, педагогизация родителей, взаимодействие, сотрудничество, партнерство.

Ivakh S. The features of parents' pedagogisation of preschool children.

The article emphasizes the importance of the close relationship of the family and kindergarten to create one for each childsentrystic educational environment. It also singles out the basic principles of their interaction and substantiates effective forms and methods of their collaboration.

Key words: pre-school, family, parents' pedagogisation, interaction, collaboration, partnership.

Ідея взаємозв'язку суспільного й сімейного виховання знайшла своє відображення в низці нормативно-правових документів нашої держави: Концепції дошкільного виховання в Україні, Державній національній програмі «Освіта. Україна XXI ст.», Законі України «Про дошкільну освіту», «Базовому компоненті дошкільної освіти в Україні» та Базовій програмі розвитку дитини дошкільного віку «Я у Світі» та ін. У них декларуються зміни щодо позиції дошкільного закладу в роботі з сім'єю.

Так, у Базовій програмі «Я у Світі» зазначено, що модернізація дошкільної освіти не може не торкнутися сучасної сім'ї, лишити родину стороннім спостерігачем змін, що відбуваються у першій іiі ланці, не обмежувати іiі інтересів. Відповідно до цього кожен дошкільний навчальний заклад не тільки виховує дітей, а й консультує батьків 3 питань їхнього виховання. Надання батькам допомоги в актуальних виховних питаннях сприяє 
формуванню взаєморозуміння в родинно-педагогічному колективі, обміну виховним досвідом. Це необхідно для того, щоб, з одного боку, сформувати у батьків правильне уявлення про свою дитину, об'єктивно оцінити іï, а з іншого, - допомагає педагогам визначити оптимальні шляхи всебічного розвитку малюка.

Актуальним у цьому контексті є оновлення стратегії й тактики взаємодії педагогів із батьками, зміни ii векторів та акцентів, осучаснення предмета розмов, розширення спектру життєво важливих проблем, надання їхній співпраці більшої щирості, відвертості, конструктивності, звільнення від надмірної формалізованості.

Питання взаємодії дошкільного навчального закладу і сім’ї перебуває в полі зору сучасних дослідників. Науковцями досліджено такі аспекти окресленої проблеми: етикопедагогічні вимоги до взаємин із дітьми та їхніми батьками (Т. Кирієнко [3], Л. Сухарева [11]); зміст і методи педагогічної взаємодії з батьками (О. Долинна [2], М. Спичак [10], О. Низковська [2]); умови для спільної роботи сім’ї і педагогічного колективу ДНЗ у формуванні моральних якостей особистості дитини (Т. Алексєєнко [1], Л. Божович， В. Постовий [7]); особливості взаємодії з батьками дітей раннього віку (Н. Аксаріна, О. Волкова, Т. Маркова, Л. Свирська [8]) тощо.

Водночас, незважаючи на широкоапектність вивчення окресленої проблематики, питання формування педагогічної культури батьків дошкільників донині залишаються не повною мірою дослідженими. Тому метою статті є обгрунтування ефективних форм та методів педагогізації батьків дітей дошкільного віку.

Останніми роками зростає розуміння батьками переваг виховання дитини в сім’ї, а зниження рівня зайнятості дорослого населення та подовження тривалості відпустки матері по догляду за дитиною до $3-6$ років створюють для цього сприятливі умови. Проте потенціальні можливості сім’ї не завжди реалізуються. Збіднення змісту спілкування, дефіцит тепла та уважного ставлення одне до одного, поступове зникнення спільних форм корисної діяльності дитини й дорослих породжують несприйнятливі форми самоствердження дитини, конфлікти й серйозні непорозуміння.

Щоб уникнути в сім'ях непорозумінь, зберегти здоров'я батьків і їхніх дітей, сім'ям обов'язково потрібна педагогічна та психологічна допомога. Успішна виховна робота немислима без системи педагогічної освіти, підвищення педагогічної культури батьків, що є невід'ємним складником загальної культури.

Під педагогічною культурою батьків розуміється їхня підготовленість, розвиток тих якостей особистості, які відбивають ступінь їхньої зрілості як вихователів і виявляються у процесі сімейного й суспільного виховання дітей.

Провідним компонентом педагогічної культури батьків $\epsilon$ їхня педагогічна підготовленість, що характеризується певною сукупністю психолого-педагогічних, фізіолого-гігієнічних i правових знань, а також уміннями й навичками батьків, виробленими у процесі практики виховання дітей. Суттєвим при цьому є й ставлення батьків до виховання, оскільки відповідальне ставлення до батьківських обов'язків, бажання якнайкраще виховати своїх дітей - невід'ємна складова частина педагогічної культури батьків.

Отже, педагогічна культура - компонент загальної культури людини, в якому знаходить відображення накопичений попередніми поколіннями досвід виховання дітей у сім’ї, що постійно збагачується. Виявляється у ставленні до дитини, в оцінці ії поведінки, а також у реальній діяльності і спілкуванні з нею[7, с. 216].

Методологічною основою педагогічної освіти батьків є: народний педагогічний досвід та досягнення вітчизняної та зарубіжної наукової педагогіки 3 питань родинного виховання. Щоб педагогізація батьків була достатньо ефективною, вона має бути диференційованою. Тобто передбачати якісні відмінності та особливості різних груп сімей, до яких відносяться: соціальні аспекти (особливості сімей за місцем проживання, соціальний статусу сім’ï); демографічний аспект (урахування віку, освіти батьків та дітей, структури сім’і); світоглядний (світоглядні позиції, стиль сімейних стосунків, ставлення 
до суспільства); етнографічний (урахування рівня загальної педагогічної та професійної культури батьків, характер сімейних традицій, культури домашнього побуту) [14, с. 67].

Щодо форм співробітництва дошкільного закладу 3 родинами, то на практиці позитивно зарекомендували себе такі форми як: індивідуальні, групові, колективні. Найпоширеніша форма індивідуальної роботи з родиною - консультації та бесіди. Бесіди як найбільш поширена форма індивідуальної роботи надають змогу зрозуміти окремі вчинки і переживання дітей, допомагають педагогам та батькам ближче познайомитися, тримати один одного в курсі життя дитини. Такі бесіди - перші кроки до добрих, довірливих взаємин між сім'єю та вихователем. Тематика бесід диктується життям дитини вдома та в дошкільному закладі: «Як відбувається фізичний розвиток дитини?», «Чим дитина цікавиться?», «Режим роботи ДНЗ».

Бесіда $з$ батьками передбачає чітке формулювання мети: що саме вихователь хоче з'ясувати, довідатись, а також продумування способу іiї досягнення. Вона не може вести спостереження стихійно, отже, воно потребує підготовки. Мета підказує тему, а тема моделює хід бесіди. Перші бесіди повинні бути короткими і побудованими на значимому для батьків змісті. Питання, які продумані педагогом заздалегідь, вплітаються в хід бесіди. Одне і те ж питання доцільно ставити в різних формах у декількох бесідах, тоді $\epsilon$ впевненість у правдивості одержаного матеріалу і значущості прикінцевих результатів.

До бесід близькі консультації (групові та індивідуальні). Кожна консультація припускає не тільки обговорення проблеми, але й практичні рекомендації щодо іiі розв'язання. Проводячи консультації, потрібно намагатись, щоб вони були перспективними і сприяли реальним змінам у родині на краще. Вибір теми потрібно визначати спостереженням за дітьми або завданнями виховання : «Про дитячу чуйність $\mathrm{i}$ жорстокість», «Дитина у світі прекрасного», «Джерело розвитку особистості дитини».

3-поміж індивідуальних форм роботи слід виокремити й відвідування сім'ї дитини. Однак останнім часом ця форма роботи неправомірно втратила своє послідовне використання, що збіднює можливості вихователів, оскільки встановлення особистісного контакту надає змогу об'єктивно з'ясувати педагогічну позицію сім’і, ознайомитися 3 умовами, в яких живе дитина, тактовно допомогти родині зрозуміти та виправити якісь помилки або вжити рішучих заходів щодо оздоровлення виховної ситуації в сім'ї в цілому. Плануючи відвідування певної сім'ї, вихователь повинен, передусім, поставити мету: ближче ознайомитись з батьками, краще дізнатись про сім'ю, побачивши іiі в звичайних, домашніх умовах, перевірити свої припущення і спостереження відносно психологічного клімату, в якому живе дитина. Обов'язково слід попереджувати сім'ю про свої візити, узгодивши з батьками день і місце, час відвідин, зручний для обох сторін.

Для групової роботи варто об’єднувати родини з подібними проблемами у вихованні дитини: ті, наприклад, де занадто вимогливі, суворі, жорсткі батьки, або родини, де повсякчас виникають конфлікти між дитиною та батьками тощо. Для таких груп родин варто розробити конкретні рекомендації, поради, які допомогли б виправити становище (надання відповідної методичної літератури, побудова конкретної та посильної моделі дій, проведення тренінгів, консультацій, ознайомлення з кращим досвідом інших родин тощо).

Позитивно зарекомендували себе такі активні форми роботи з батьками як семінарипрактикуми та тематичні консультації. Семінари-практикуми, зазвичай, присвячено одній виховній проблемі. Ефективність їх проведення забезпечується активною участю батьків, яких цікавить проблема, що обговорюється. Тематичні консультації можуть бути плановими і неплановими та поділяються на індивідуальні й групові. Вони допомагають, 3 одного боку, - вихователям краще дізнатися про життя сімей вихованців і надати кваліфіковану допомогу тим, хто нагайно іiі потребує, а 3 іншого, - спонукає батьків придивитись до своїх дітей, виявити риси їх характеру, задуматися над тим, які методи та засоби краще застосовувати у їхньому вихованні. Матеріалом для консультацій слугують щоденні спостереження вихователя за поведінкою дітей в дошкільному навчальному закладі, за взаємовідносинами батьків і дітей, бесіди з членами родин вихованців. Під час 
проведення консультацій важливо, щоб батьки відчували щиру зацікавленість вихователя, впевненість у його доброзичливих намірах та професійній компетентності. Зазвичай консультації порушують питання корекційних технологій, які можуть бути використані батьками в домашніх умовах. У процесі проведення таких консультацій розв'язуються конкретні проблеми, які виникають у батьків у різних виховних моментах. Основна мета цих форм роботи - максимально допомогти батькам правильно побачити особливості дитини, його реальні можливості та причини невдач, зорієнтувати їх на більш ефективне використання доступних їм засобів при допомозі педагогів, психологів, лікарів.

Програма індивідуальних консультацій з батьками передбачає:

1) ознайомлення 3 проблемою, яку виокремлюють батьки; іiі обговорення; виявлення соціальної ситуації розвитку дитини;

2) обговорення напрямів корекційної роботи і можливостей ï реалізації за активної участі батьків;

3) виявлення стилю батьківського виховання, визначення чинників, які перешкоджають розв'язанню проблеми й обговорення можливого напряму їх корекції;

4) обговорення комплексу корекційних вправ, які будуть виконуватися 3 дитиною вдома, а також режиму, дозування часу на їх проведення, стилю взаємодії батьків 3 дитиною в процесі корекції;

5) обговорення результатів корекції - динаміки емоційного стану дитини й рівня сформованості функцій, які коректуються; обговорення труднощів реалізації колекційної програми та способів їх подолання;

6) зворотній зв'язок, який передбачає перенесення нерозв'язаних проблем у процес виховної роботи дошкільного навчального закладу [3, с. 8].

Важливою формою групової роботи з батьками є конференції. Вони мають на меті розширення, поглиблення і закріплення знань про освіту й виховання дітей, можуть бути як науково-практичними, так і теоретичними. Їх доцільно проводити як обмін досвідом із виховання дітей або думками з певної проблеми. Конференції, як і будь-яку зустріч із батьками, слід ретельно готувати та планувати заздалегідь: провести відповідну літературну виставку, вивчити думки дорослих, дітей і видатних вчених. Темою для обговорення можуть бути й нагальні проблеми дошкільного навчального закладу: оформлення і ремонт групи, моральні й естетичні організації святкових ранків тощо.

Однією з нетрадиційних форм групової роботи $є$ тренінги. Батьківські тренінги - це досить ефективна й активна форма роботи з батьками, які усвідомлюють наявні проблеми родини, прагнуть змінити стиль взаємодії з власною дитиною, розуміють необхідність набуття нових знань і вмінь у їі вихованні. Під час тренінгових занять батьки з великим інтересом виконують такі завдання, як «дитячі ігри», «улюблена іграшка», «мій казковий образ».

Простором для виявлення творчості є така форма групової роботи, як ділові ігри. Вони максимально наближують учасників гри до реальних обставин, формують навички швидкого прийняття педагогічно правильних рішень, умінь вчасно побачити та виправити педагогічну помилку.

Ділова гра складається з таких компонентів:

- підготовчий етап, який передбачає визначення мети та завдань гри, організаційні правила, які регламентують хід гри, розподіл ролей;

- хід гри, який полягає у виконанні всіма учасниками гри необхідних правил і дій;

- підсумок гри, що полягає в аналізі їі результатів [11, с. 54].

Метою проведення ділових ігор є вироблення і закріплення певних навичок, націлених на розвиток рефлексивних здібностей батьків, уміння попередити різноманітні конфліктні ситуації, що виникають у процесі виховання дітей.

Індивідуальні та групові форми роботи підвищують довіру батьків до педагога, його порад рекомендацій, сприяють налагодженню партнерських взаємин між батьками та вихователями. Членів родини залучають до участі в підготовці та проведенні ранків, 
тематичних виставок-консультацій, конференцій з обміну досвідом родинного виховання. Ведення журналів запитань та відповідей допомагає встановити тісний зворотний зв'язок. Усі означені форми роботи між членами родин та педагогами покликані активізувати педагогічне навчання, загальна мета якого - підвищити педагогічну і психологічну освіту дорослих, сприяти грамотному застосуванню ними знань у царині сімейного виховання.

Отже, формування педагогічної культури батьків розпочинається з усвідомлення ними можливостей i потреб особистого внутрішнього вдосконалення. Це постійний процес свідомого саморозвитку дорослих, що потребує використання цілісної педагогічної системи як певної сукупності взаємопов'язаних засобів і методів, необхідних для забезпечення організованого, цілеспрямованого й прогнозованого впливу на формування особистості із заданими якостями. Усі форми педагогічної роботи з батьками, що проводяться в дошкільному навчальному закладі повинні: враховувати право батьків на власну думку, позицію, систему цінностей; інформувати їх не лише про обов'язки, але й про права, якими вони можуть скористатись; позитивно ставитись до виявів батьківської ініціативи і творчості.

\section{Література}

1. Алексєєно Т. Формування педагогічної культури сучасної молодої сім’ї Т. Алексеєнко // Рідна школа. - 1998. - № 1 - 2. - С. 46-47. 2. Долинна О. Батьки в дошкільному закладі: споживачі та гості чи партнери-однодумці? / О. Долинна, О. Низковська // Дошкільне виховання. 2007. - № 1. - С. 6-8. 3. Кирієнко Т. Співпраця з родиною. Семінар для педагогів / Т. Кірієнко // Дошкільне виховання. - 2006. - № 10. - С. 7-9. 4. Назаренко А. Сім’я і дошкільний заклад / А. Назаренко // Дошкільне виховання - 1995. - № 8. - С. 11. 5. Островська Л. Ф. Сімейне виховання дошкільника / Л. Ф. Островська. - К., 1977. - 121 с. б. Пеньковська Н. Сім'я формує самооцінку дитини / Н. Пеньковська // Дошкільне виховання. - 2002. - № 6. - С. 16-19. 7. Постовий В. Сучасна сім’я і їі педагогіка / В. Постовий. - К., 1994. - 224 с. 8. Свирська Л. Взаємодія дорослих із дітьми раннього віку / Л. Свирська, Н. Петрова. - К., 2004. - 112 с. 9. Спиваковская А. С. Как быть родителями / А. С. Спиваковская. - М., 1986. - 332 с. 10. Спичак М. Курс на співпрацю з батьками / М. Спичак // Дошкільне виховання. - 2007. - № 3. - С. 14. 11. Сухарева Л. С. Піклуємось разом. Робота з батьками дошкільників / Л. С. Сухарева. Х. : Основа : Тріада, 2008. - 128 с. 12. Терещенко О. Родинні збори в дитячому садку / О. Терещенко // Дошкільне виховання. - 2007. - № 2. - С. 18-20. 13. Тоцька Т. Виховувати серцем / Т. Тоцька // Дошкільне виховання. - 2007. - № 3. - С. 14-17. 14. Федорович Л. Дидактичні принципи моделювання взаємодії сім'ї, дошкільної установи, школи / Л. Федорович // Рідна школа. - 1999. - № 9. - С. 65-68. 15. Хромова О. Л. Педагогічний всеобуч батьків /О. Л. Хромова, Т. В. Кравченко. - К. : Знання, 1990. - 32 с.

\section{МОВНА СИТУАЦІЯ ПІВДЕННО-СХІДНОГО РЕГІОНУ І ВРАХУВАННЯ ЇЇ ВПЛИВУ НА ПРОЦЕС НАВЧАННЯ ДОШКІЛЬНИКІВ УКРАЇНСЬКОЇ МОВИ}

Казанцева Л. І. Мовна ситуація південно-східного регіону і врахування ії впливу на процес навчання дошкільників української мови.

У статті визначено особливості стану мовної ситуації південно-східного регіону України, надано характеристику соціомовленнєвого середовища як чинника формування мовної особистості дитини-дошкільника.

Ключові слова: мовна ситуація, соціомовленнєве середовище, двомовність, рідна мова, домінантна мова, україномовний, російськомовний.

Казанцева Л. И. Языковая ситуация юго-восточного региона и учет её влияния на процесс обучения дошкольников украинсконскому языку. 